\title{
Evidence that the TRH-like peptide pyroglutamyl-glutamyl- prolineamide in human serum may not be secreted by the pituitary gland
}

\author{
W J de Greef, W W de Herder ${ }^{1}$, C B Lambalk ${ }^{2}$, W Klootwijk ${ }^{1}$, \\ E Sleddens-Linkels, $\mathbf{F} \mathbf{H}$ de Jong and $\mathbf{T}$ J Visser ${ }^{1}$ \\ Department of Endocrinology and Reproduction, ${ }^{1}$ Department of Internal Medicine and Clinical Endocrinology, Erasmus University, Rotterdam, \\ The Netherlands and ${ }^{2}$ Division of Reproductive Endocrinology, Research Institute for Endocrinology, Reproduction and Metabolism, \\ Free University Amsterdam, The Netherlands \\ (Requests for offprints should be addressed to W J de Greef, Department of Endocrinology and Reproduction, Faculty of Medicine and Health Sciences, \\ Erasmus University, PO Box 1738, 3000 DR Rotterdam, The Netherlands)
}

\begin{abstract}
Recent studies have revealed that TRH-like immunoreactivity (TRH-LI) in human serum is predominantly $p$ Glu-Glu-ProNH $H_{2}\left(<\right.$ EEP-NH $\left.{ }_{2}\right)$, a peptide previously found in, among others tissues, the pituitary gland of various mammalian species. In the rat pituitary, $<\mathrm{EEP}-$ $\mathrm{NH}_{2}$ is present in gonadotrophs and its pituitary content is regulated by gonadal steroids and gonadotrophin-releasing hormone $(\mathrm{GnRH})$. Hence, we reasoned that $<\mathrm{EEP}-\mathrm{NH}_{2}$ in human serum may also arise, at least in part, from the pituitary, and that its secretion may correlate with that of gonadotrophins. Therefore, blood was simultaneously sampled from both inferior petrosal sinuses, which are major sites of the venous drainage of the pituitary gland, and a peripheral vein from seven patients with suspected adrenocorticotrophin-secreting pituitary tumours. In addition, in six postmenopausal and six cyclic women, peripheral vein blood was collected at 10-min intervals for $6 \mathrm{~h}$, then a standard $100 \mu \mathrm{g} \mathrm{GnRH}$ test was performed. In the sera, TRH-LI was estimated by RIA with antiserum 4319, which binds most tripeptides that share the $\mathrm{N}$ - and C-terminal amino acids with TRH ( $p$ Glu-His-ProNH $\left.{ }_{2}\right)$. In addition, $\mathrm{LH}$ and $\mathrm{FSH}$ were measured in these sera by RIA. In the blood samples taken at 10-min intervals, an
\end{abstract}

episodic variation in serum TRH-LI was noted and pulses of TRH-LI were detected at irregular intervals (from one to six pulses per $6 \mathrm{~h}$ ) in five postmenopausal and six cyclic women. In general, these pulses did not coincide with those of LH and FSH, suggesting that TRH-LI is not co-secreted with gonadotrophins. Moreover, unlike LH and FSH, serum TRH-LI did not increase during the menopause or after exogenous administration of $\mathrm{GnRH}$. Whereas gonadotrophin concentrations were significantly greater in the inferior petrosal sinus than in peripheral serum, there were no differences in TRH-LI concentrations between these serum samples. In conclusion, serum TRH-LI in humans seems not to be regulated by gonadal steroids or GnRH. Moreover, serum derived directly from the pituitary contained no more TRH-LI than did peripheral serum, which suggests that the human pituitary gland does not secrete significant amounts of $<$ EEP- $\mathrm{NH}_{2}$, and therefore does not contribute significantly to serum TRH-LI concentrations. Further research is required to identify the site of origin of $<\mathrm{EEP}-\mathrm{NH}_{2}$ in human serum.

Journal of Endocrinology (1997) 155, 393-399

\section{Introduction}

Thyrotrophin-releasing hormone (TRH) was originally isolated from hypothalamic extracts. Subsequently, TRHlike immunoreactivity (TRH-LI) was detected in peripheral tissues, blood and urine (for reviews, see Hökfelt et al. 1989, Ashworth 1994, Iversen 1995). Although TRH-LI in the brain and certain peripheral tissues has been identified as authentic TRH (Pekary et al. 1980, 1993, Ashworth 1994, Iversen 1995, Klootwijk et al. 1997a), TRH-LI in other tissues is attributable to peptides that are structurally related to TRH (Cockle et al. 1989, Khan et al. 1992, Ashworth 1994, Gkonos et al. 1994, Cockle 1995, Rondeel et al. 1995a,b, Linden et al. 1996). These TRH-like peptides, which differ from TRH ( $p$ GluHis-ProNH $\mathrm{H}_{2}$ ) in the middle amino acid, cross-react to varying extents with antisera raised against TRH (Pekary et al. 1993, Rondeel et al. 1995a, Klootwijk et al. 1995, 1996). The knowledge of the function of these TRH-like peptides remains limited, but physiological actions have been reported for $p$ Glu-Glu-ProNH ${ }_{2}\left(<\mathrm{EEP}-\mathrm{NH}_{2}\right)$, a peptide detected first in the prostate gland (Cockle et al. 
Table 1 Characteristics of TRH-LI, LH and FSH in serum of postmenopausal $(n=6)$ and premenopausal $(n=6)$ women. Blood was taken from these volunteers at 10-min intervals for $6 \mathrm{~h}$. Premenopausal women were studied at day 3 of the menstrual cycle. Results are means \pm S.E.M.

\begin{tabular}{|c|c|c|}
\hline & Postmenopausal & Premenopausal \\
\hline \multicolumn{3}{|l|}{ Variable } \\
\hline \multicolumn{3}{|l|}{$\mathrm{TRH}-\mathrm{LI}$} \\
\hline Mean concentration $(\mathrm{pg} / \mathrm{ml})$ & $16 \cdot 4 \pm 1 \cdot 7$ & $21 \cdot 6 \pm 3 \cdot 0$ \\
\hline Mean amplitude $(\mathrm{pg} / \mathrm{ml})$ & $13 \cdot 3 \pm 1 \cdot 3$ & $17 \cdot 1 \pm 2 \cdot 4$ \\
\hline Pulses per $6 \mathrm{~h}$ & $2 \cdot 7 \pm 1 \cdot 0$ & $3 \cdot 3 \pm 0 \cdot 7$ \\
\hline \multicolumn{3}{|l|}{$\mathrm{LH}$} \\
\hline Mean concentration $(\mathrm{mU} / \mathrm{ml})$ & $19 \cdot 2 \pm 3 \cdot 1$ & $3 \cdot 2 \pm 0 \cdot 8^{*}$ \\
\hline Mean amplitude $(\mathrm{mU} / \mathrm{ml})$ & $4 \cdot 1 \pm 0 \cdot 4$ & $1 \cdot 1 \pm 0 \cdot 3^{*}$ \\
\hline Pulses per $6 \mathrm{~h}$ & $4 \cdot 3 \pm 0 \cdot 3$ & $4 \cdot 5 \pm 0 \cdot 3$ \\
\hline \multicolumn{3}{|l|}{ FSH } \\
\hline Mean concentration $(\mathrm{mU} / \mathrm{ml})$ & $68 \cdot 1 \pm 11 \cdot 4$ & $7 \cdot 3 \pm 1 \cdot 7^{*}$ \\
\hline Mean amplitude $(\mathrm{mU} / \mathrm{ml})$ & $6 \cdot 4 \pm 1 \cdot 5$ & $1 \cdot 0 \pm 0 \cdot 3^{*}$ \\
\hline Pulses per $6 \mathrm{~h}$ & $4 \cdot 7 \pm 0 \cdot 7$ & $3 \cdot 2 \pm 0 \cdot 5$ \\
\hline
\end{tabular}

${ }^{*} P<0 \cdot 05$ compared with postmenopausal women.

1989) and later in semen and the anterior pituitary gland of various mammalian species (for reviews, see Ashworth 1994, Cockle 1995), in a human neuroblastoma cell line (Rondeel et al. 1994) and in serum and urine of patients with metastatic carcinoid tumours (Klootwijk et al. 1996, 1997b). Recently, <EEP-NH 2 has been found to enhance the fertilizing ability of human and mouse sperm (Green et al. 1994, 1996a), to inhibit the acrosome reaction of mouse sperm (Green et al. 1996b), to increase the motility of sperm from certain infertile men (Linden et al. 1996), to affect pituitary growth hormone release in domestic fowls and rats (Harvey et al. 1993. Ashworth et al. 1994, Rondeel et al. 1995b) and to inhibit adrenal corticosterone secretion in rats (Neri et al. 1993). Because of its effect on sperm, $<$ EEP-NH $\mathrm{NH}_{2}$ has also been called fertilization promoting peptide (FPP, Cockle 1995).

Serum of healthy humans also contains TRH-LI that is not identical to TRH (Iversen 1986), and recent data show that the predominant TRH-like peptide in human and rat serum is <EEP-NH ${ }_{2}$ (Bertram \& Cockle 1995, Klootwijk et al. 1997a,b). Although prostatic secretion of $<$ EEP-NH $\mathrm{N}_{2}$ may contribute to serum concentrations of TRH-LI in men (Bertram \& Cockle 1995, Klootwijk et al. 1997b), the similarity of serum TRH-LI in men and women (Klootwijk et al. 1996, 1997b) indicates that other sources of $<$ EEP- $\mathrm{NH}_{2}$ exist. Studies in rats have provided suggestive evidence that $<\mathrm{EEP}-\mathrm{NH}_{2}$ in the pituitary gland is produced by the gonadotrophs (Rondeel et al. $1995 a, b)$, and have revealed that the pituitary content of $<$ EEP-NH $\mathrm{N}_{2}$ is influenced by treatments affecting gonadotrophin release (Akinsanya et al. 1995, Rondeel et al. $1995 a, b)$. We have studied the possibility that, in human serum, $<E E P-\mathrm{NH}_{2}$ is derived at least in part from hypophysial secretion, and that this secretion is correlated with that of gonadotrophins.

\section{Study participants and methods}

All studies were performed according to the rules of the respective medical ethics committees of the University Hospitals of Amsterdam and Rotterdam.

Profiles of TRH-LI and gonadotrophins in peripheral serum of postmenopausal and cyclic women

Twelve healthy women volunteers, six postmenopausal (aged 52-72 years, median 57 years) and six premenopausal women at day 3 of the menstrual cycle (ages 32-38 years, median 36 years), participated in the study. A cannula was placed in a peripheral vein at between 0800 and $0900 \mathrm{~h}$, and blood samples were removed from the cannula every $10 \mathrm{~min}$ for $6 \mathrm{~h}$. At the end of the $6 \mathrm{~h}$ period, $100 \mu \mathrm{g}$ gonadotrophin-releasing hormone (GnRH; Wyeth, Hoofddorp, The Netherlands) was injected through the cannula and additional blood samples were taken 30,60 and $90 \mathrm{~min}$ later. Blood was allowed to clot and serum was kept at room temperature for at least $2 \mathrm{~h}$ to ensure the enzymatic degradation of any endogenous TRH-LI that was not identical to $<$ EEP-NH $\mathrm{N}_{2}$ (Cockle et al. 1994, Klootwijk et al. 1997b) by serum pyroglutamyl aminopeptidase II (Schauder et al. 1994). The serum samples were stored at $-20{ }^{\circ} \mathrm{C}$ until required for analysis for TRH-LI, luteinizing hormone (LH) and follicle-stimulating hormone (FSH) by RIA.

\section{Concentrations of TRH-LI and gonadotrophins in peripheral and inferior petrosal sinus serum}

Synchronous blood samples were obtained from both inferior petrosal sinuses and from a peripheral vein as described previously (de Herder et al. 1994), for the 

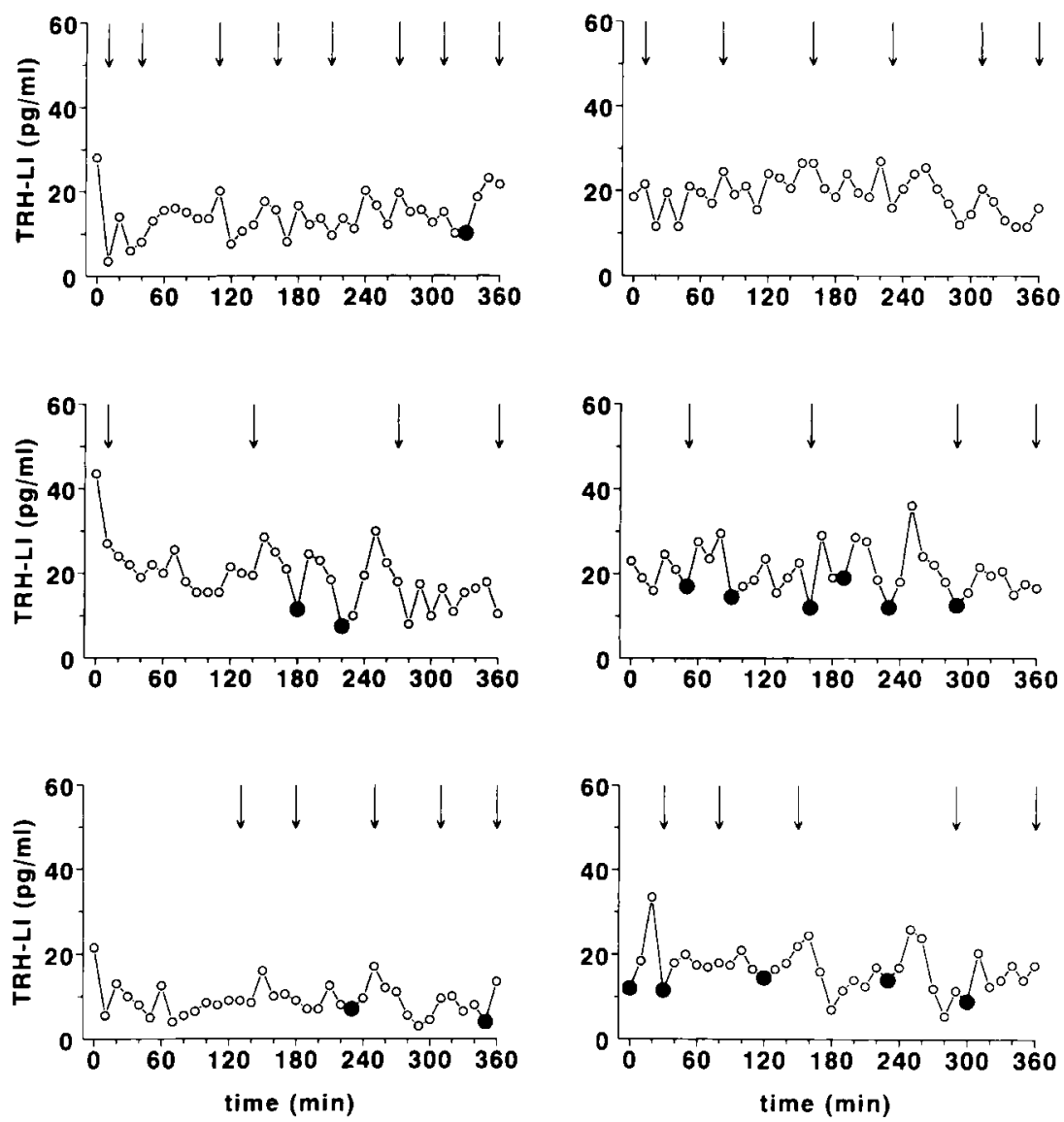

Figure 1 Patterns of serum concentrations of TRH-LI in individual postmenopausal women. Blood samples were taken every 10 min for $6 \mathrm{~h}$. - , nadir of detected TRH-LI pulses; arrows indicate the occurrence of $\mathrm{LH}$ pulses.

diagnosis of pituitary-dependent Cushing's disease in four women (aged 25-73 years, median 40 years) and three men (aged 28-66 years, median 63 years). Blood was removed before $(0 \mathrm{~min})$ and several times after stimulation with corticotrophin-releasing hormone $(\mathrm{CRH}, 1 \mu \mathrm{g} / \mathrm{kg}$, Bissendorf Peptide Pharmaentwicklung und Vertrieb $\mathrm{GmbH}$, Hannover, Germany) to evaluate the response of adrenocorticotrophin (de Herder et al. 1994). On the basis of the resulting serum concentrations of adrenocorticotrophin, four of these patients were found to have Cushing's disease. Retrospectively, it was found that two patients did not suffer from Cushing's syndrome, but had generalized obesity, and one had an adrenal cortisolsecreting adenoma. The blood samples were treated as described above, and the sera were stored at $-20{ }^{\circ} \mathrm{C}$ until required for analysis.

\section{Assays}

All samples from each participant were estimated at least in duplicate in the same assay. Concentrations of TRH-LI were determined in unextracted serum by RIA with antiserum 4319, an antiserum which detects most TRHlike peptides that differ from TRH by the central amino acid - i.e. peptides with the structure $p \mathrm{Glu}-\mathrm{X}-\mathrm{ProNH}_{2}$ (Rondeel et al. 1995a, Klootwijk et al. 1995, 1996). Antiserum 4319 was used at a final dilution of 1:20 000 in the RIA, using ${ }^{125} \mathrm{I}-\mathrm{TRH}$ as tracer and unlabelled TRH as standard. The limit of detection for this assay is $3-5 \mathrm{pg}$ $\mathrm{TRH} / \mathrm{ml}$, and the intra- and interassay coefficients of variation were less than $15 \%$. Previously, we provided evidence that most TRH-LI in human serum kept at room temperature for at least $2 \mathrm{~h}$ is accounted for by $<$ EEP$\mathrm{NH}_{2}$ (Klootwijk et al. 1997b). In this paper, however, we nevertheless present the data as TRH-LI, expressed as TRH equivalents, because minor contributions from other TRH-like peptides cannot be excluded.

In the samples collected at 10-min intervals, $\mathrm{LH}$ and FSH were measured by a double antibody IRMA (IRMA-mat BYK-Sangtec Diagnostica GmbH, Dietzenbach, Germany). In inferior petrosal sinus and corresponding peripheral serum samples, gonadotrophins 

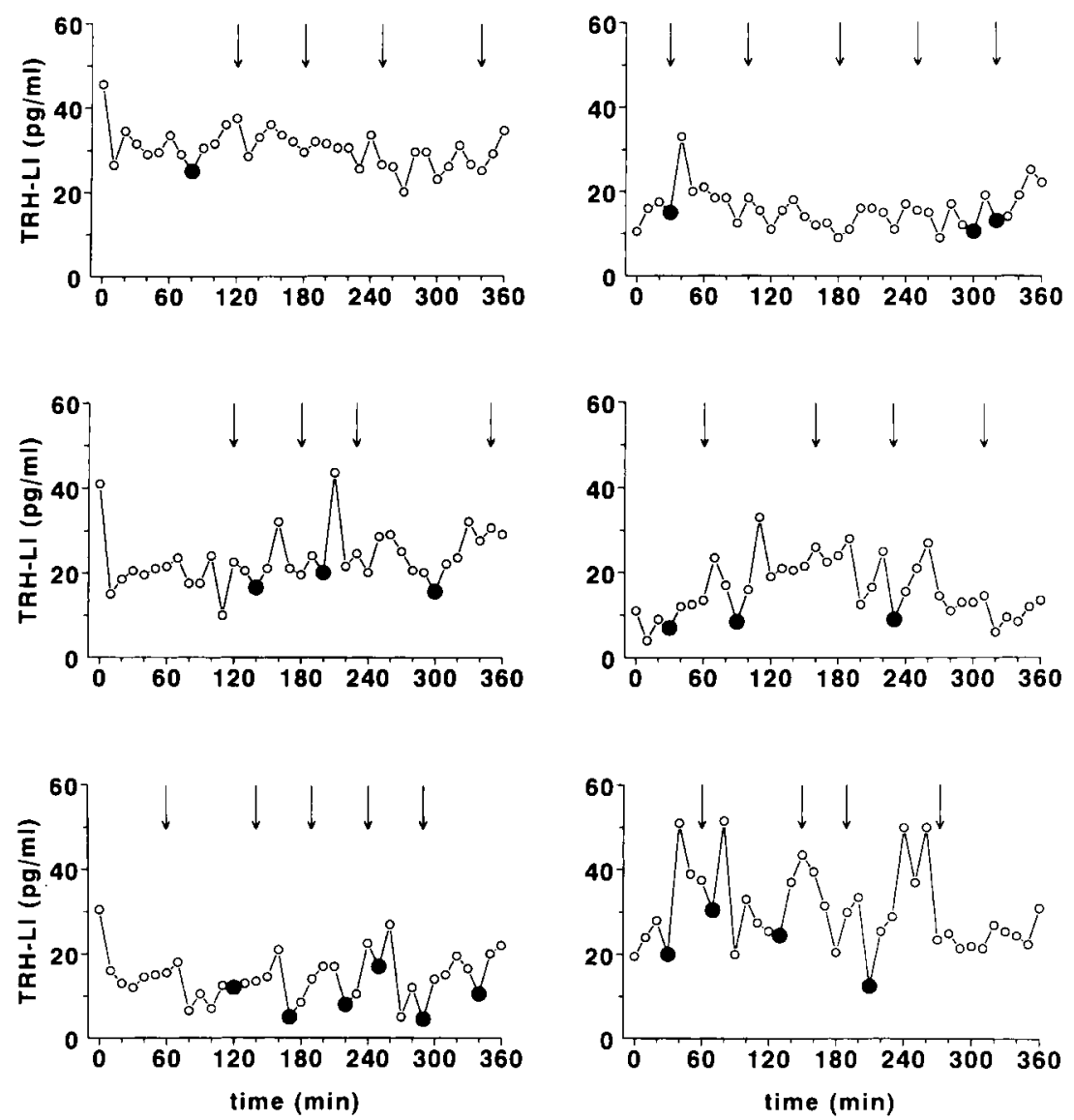

Figure 2 Patterns of serum concentrations of TRH-LI in individual fertile women on day 3 of the menstrual cycle. Blood samples were taken every $10 \mathrm{~min}$ for a period of $6 \mathrm{~h}$. - nadir of detected TRH-LI pulses; arrows indicate the occurrence of LH pulses.

were estimated using an immunometric method with an enhanced luminescence endpoint (Amerlite; Johnson \& Johnson Clinical Diagnostics, Amersham, UK). The lower limits of detection of the gonadotrophin assays were less than $0.2 \mathrm{IU} / 1$, and references for expression of $\mathrm{LH}$ and FSH were first IRP 68/40 and second IRP 78/549, respectively; the intra- and interassay coefficients of variation were less than $8 \%$.

Pulse detection of serum TRH-LI, LH and FSH was performed as described previously (Lambalk et al. 1985, Scheele et al. 1987). The algorithm of the analysis is valid for replicates of repeated measurements with a chance of less than $5 \%$ to indicate non-existing pulses as a pulse in a series of 100 samples taken from pooled serum. Nadirs preceding the pulses, rather than the pulses themselves, were used for analyses of the hormone patterns. Pulses of TRH-LI, LH and FSH were considered to be asynchronous when they started more than $10 \mathrm{~min}$ apart (Veldhuis et al. 1991). The maximum gonadotrophin and TRH-LI increments were taken as the measure of their response to $\mathrm{GnRH}$.

\section{Statistical analyses}

Results are given as means \pm s.E.M., and statistical tests included analysis of variance, Wilcoxon matched-pairs signed-ranks test and linear regression analysis. $P \leq 0 \cdot 05$ was considered significant.

\section{Results}

Small but measurable amounts of TRH-LI were detected in the serum samples. Isocratic reverse-phase high performance liquid chromatography revealed that most TRH-LI in serum of normal volunteers co-eluted with $<$ EEP-NH $\mathrm{NH}_{2}$ (data not shown). Mean serum concentrations of TRH-LI were found to be similar in cyclic and postmenopausal women, whereas serum concentrations of LH and FSH were greater in postmenopausal than in cyclic women (Table 1). An episodic variation in serum TRH-LI was observed and, in 11 women, pulses of TRH-LI were detected at irregular intervals (Figs 1 and 2). In these women, pulses occurred between one and 

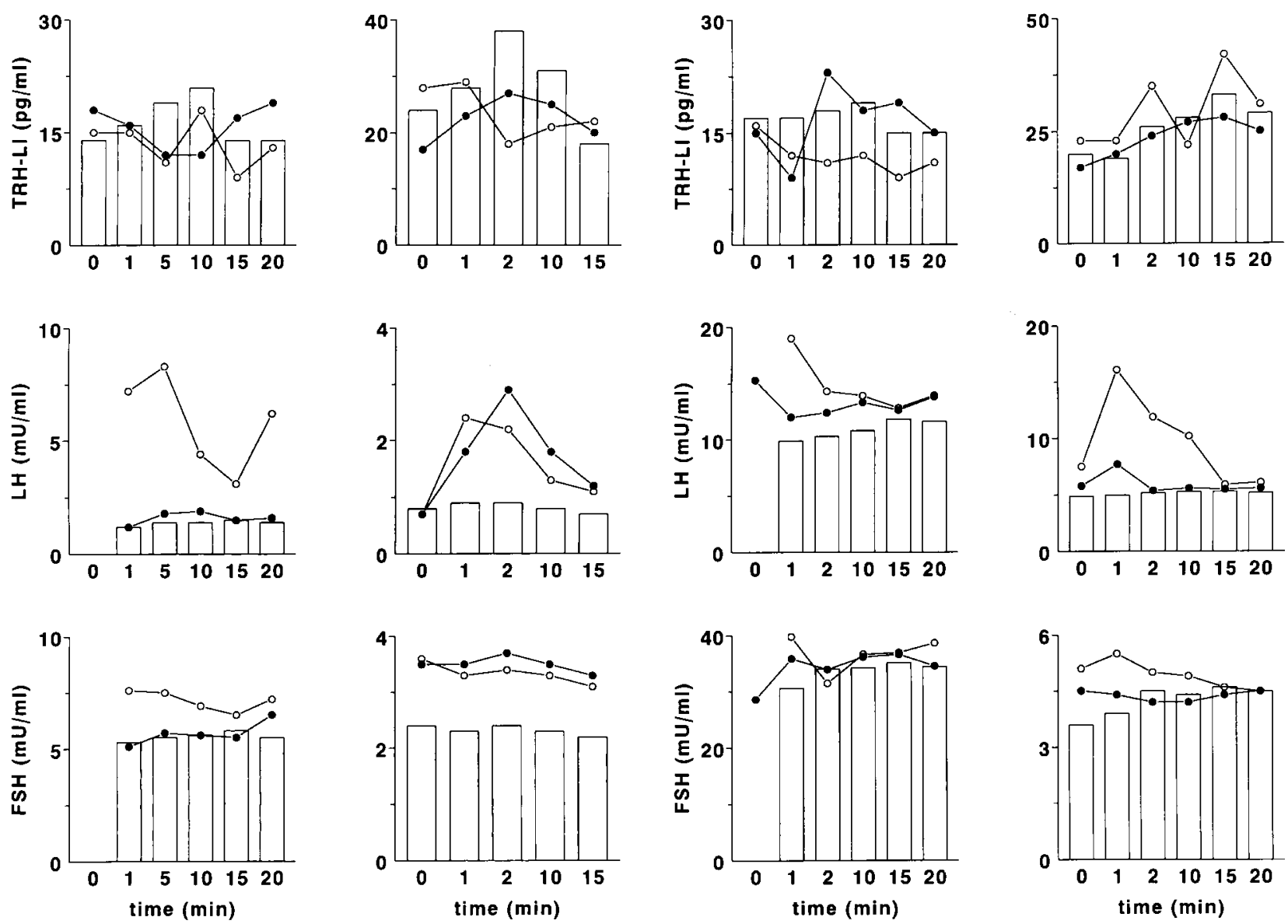

Figure 3 Concentrations of TRH-LI, $\mathrm{LH}$ and FSH in serum of two obese patients, obtained by simultaneous blood sampling of a peripheral vein (open bar) and the left $(\bigcirc)$ and right $(\bullet)$ inferior petrosal sinuses. Left: results from a 63-year-old man. Right: results from a 35-year-old woman using oral contraceptives.

six times during the period of observation, with a mean of about three pulses per $6 \mathrm{~h}$ (Table 1). The pulses of TRH-LI in these female volunteers in general did not coincide with pulses of LH (Figs 1 and 2) or FSH (data not shown). Whereas serum concentrations of LH and FSH increased significantly in all women in response to $100 \mu \mathrm{g}$ GnRH (LH: $376 \pm 28 \%$, FSH: $152 \pm 4 \% ; P<0 \cdot 01)$, no significant effect of GnRH on serum TRH-LI was observed $(122 \pm 16 \%)$.

As expected, a significant correlation $(r=0 \cdot 80, P<0 \cdot 01)$ was found between serum LH and FSH during the 6-h period of observation. In contrast, serum concentrations of TRH-LI and FSH, averaged over the 6-h period, did not correlate significantly $(r=-0 \cdot 42 ; P=0 \cdot 18)$. An almost significant inverse correlation was observed between the mean TRH-LI and LH concentrations $(r=-0.55$; $P=0 \cdot 06)$. Because of this possible negative relation, we evaluated whether peaks of TRH-LI pulses occurred
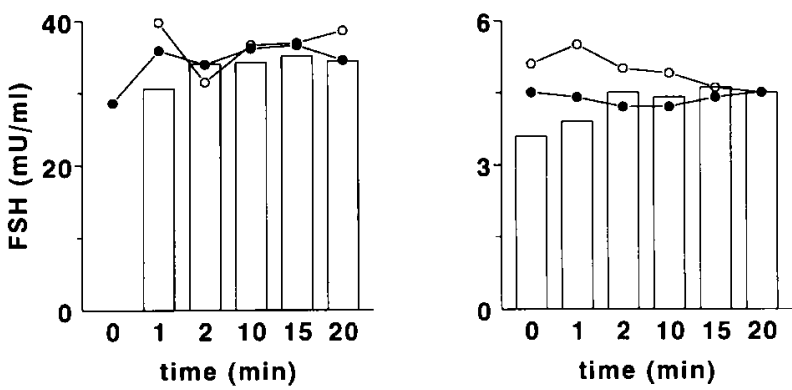

Figure 4 Concentrations of TRH-LI, LH and FSH in serum of two patients with pituitary-dependent Cushing's disease, obtained by simultaneous blood sampling of a peripheral vein (open bar) and the left $(\bigcirc)$ and right $(\bullet)$ inferior petrosal sinuses. Left: results from a 73-year-old woman. Right: results from a 66-year-old man.

within 10 min of the nadir of an LH pulse; however, this proved to be the case with only six of 36 TRH-LI pulses.

TRH-LI concentrations were found to be similar in serum obtained from the inferior petrosal sinuses or from a peripheral vein of the two obese patients (Fig. 3), the four patients suffering from pituitary-dependent Cushing's disease (Fig. 4 shows data for two of them) and the patient with a cortisol-secreting adenoma (data not shown). During the period of observation, concentrations of TRH-LI in inferior sinus petrosus serum of these seven subjects were $94 \pm 3 \%$ of those in peripheral serum. In contrast, concentrations of LH and FSH were significantly greater in inferior sinus petrosus serum than in peripheral serum (LH: $205 \pm 23 \%$, FSH: $121 \pm 6 \% ; \quad P<0 \cdot 025)$. Similar findings were made for growth hormone and prolactin (data not shown), and during the sampling period the concentrations of these hormones in inferior sinus petrosus serum were, respectively, $997 \pm 63 \%$ and $470 \pm 99 \%$ 
greater $(P<0.025)$ than the values measured in peripheral serum.

\section{Discussion}

This study concerned the presence, in human serum, of TRH-LI, concentrations of which in women were found to exhibit episodic variations. Recent data have revealed that the predominant TRH-LI in serum of normal human subjects is <EEP-NH ${ }_{2}$ (Bertram \& Cockle 1995, Klootwijk et al. 1996, 1997b, present study), and similar findings have been made for rat serum (Klootwijk et al. 1997a). Because $<$ EEP-NH $\mathrm{N}_{2}$ in the rat pituitary gland is probably synthesized by gonadotrophin-secreting cells and is regulated in a 'gonadotrophic' manner (Akinsanya 1995, Rondeel et al. 1995a,b), we hypothesized that TRH-LI in human serum originates at least in part from the pituitary gland and correlates with the secretion pattern of gonadotrophins. Our objective was to test this hypothesis.

Concentrations of TRH-LI were found to be similar in blood samples simultaneously obtained from both inferior petrosal sinuses, which are major sites of venous drainage of the anterior pituitary gland, and from a peripheral vein. Thus serum derived directly from the pituitary gland does not contain more TRH-LI than peripheral serum. This observation suggests that the pituitary gland does not secrete significant amounts of $<\mathrm{EEP}-\mathrm{NH}_{2}$. Because petrosal sinus sampling was performed in patients with suspected adrenocorticotrophin-secreting pituitary tumours, it cannot be excluded that the presence of such tumours could have resulted in the impaired secretion of TRH-LI from the pituitary gland. However, because LH and FSH concentrations were significantly greater in sinus petrosus serum than in peripheral serum during the period of observation, it seems unlikely that the presence of adenomas prevented the pituitary release of TRH-LI. Moreover, in two obese patients without a tumour, TRH-LI concentrations were similar in sinus petrosus and peripheral serum.

The lack of difference between TRH-LI concentrations in sinus petrosus and peripheral serum may also be explained by a long half-life of $<\mathrm{EEP}-\mathrm{NH}_{2}$ in blood, which would mask potential pituitary secretion of this peptide. In rats, the disappearance of $<$ EEP- $\mathrm{NH}_{2}$ from serum (Klootwijk et al. 1997a) is comparable to that of FSH and LH (de Greef et al. 1983), and intravenously injected $<$ EEP- $\mathrm{NH}_{2}$ could be recovered unchanged and quantitatively in urine (Klootwijk et al. 1997a). In humans also, serum $<$ EEP- $\mathrm{NH}_{2}$ is cleared by renal excretion and its urinary clearance rate is similar to the glomerular filtration rate (Klootwijk et al. 1997b). Thus these data suggest that the similar TRH-LI concentrations in sinus petrosus and peripheral serum are not caused by a long half-life of $<$ EEP-NH $\mathrm{N}_{2}$.

We also investigated whether TRH-LI was co-secreted with $\mathrm{LH}$ or FSH in healthy female volunteers. Although serum concentrations of TRH-LI were found to fluctuate, the pulses were not synchronous with those of LH or FSH, but rather, an almost significant inverse correlation was found between the mean TRH-LI and LH concentrations. These findings indicate that, at least in human females, TRH-LI is probably not co-secreted with gonadotrophins.

Because the $<$ EEP-NH $\mathrm{NH}_{2}$ content in rat pituitary is affected by both gonadectomy and GnRH (Akinsanya et al. 1995, Rondeel et al. 1995a,b), we also analysed the effect of menopause and GnRH on serum TRH-LI in women. Although serum concentrations of $\mathrm{LH}$ and $\mathrm{FSH}$ were greater in postmenopausal than in cyclic women, TRH-LI values were similar in both groups of women. Moreover, whereas administration of GnRH invariably increased serum concentrations of LH and FSH in both cyclic and postmenopausal women, no consistent acute effect of GnRH on serum TRH-LI was observed.

In conclusion, serum TRH-LI was found to exhibit an episodic variation. Although $<\mathrm{EEP}-\mathrm{NH}_{2}$ has been found in the anterior pituitary gland of various mammalian species (Cockle 1995), our observations do not provide evidence that, in humans, hypophysial secretion of $<$ EEP$\mathrm{NH}_{2}$ contributes significantly to serum concentrations of TRH-LI. Thus further research is required to identify the site of origin of $<$ EEP- $\mathrm{NH}_{2}$ in human serum.

\section{Acknowledgements}

The authors wish to thank the nursing staff for their generous help and excellent patient care.

\section{References}

Akinsanya KO, Ghatei MA \& Bloom SR 1995 Gonadal steroids regulate rat anterior pituitary levels of TSH-releasing hormone- and pyroglutamyl-glutamyl-proline amide-like immunoreactivity. Endocrinology 136 734-740.

Ashworth RJ 1994 Thyrotropin-releasing hormone (TRH)-related peptides. Molecular and Cellular Endocrinology $101 \mathrm{C} 1-\mathrm{C} 3$.

Ashworth RJ, Ham J \& Cockle SM 1994 The effects of pyroglutamylglutamylprolineamide, a peptide related to thyrotrophin-releasing hormone, on rat anterior pituitary cells in culture. Journal of Endocrinology 142 111-118.

Bertram C \& Cockle SM 1995 Detection of a novel peptide in blood from patients with benign prostatic hyperplasia: a new test for prostatic disease? Journal of Endocrinology 147 (suppl) O53 (Abstract).

Cockle SM 1995 Fertilization promoting peptide (FPP): a novel peptide, structurally similar to TRH, with potent physiological activity. Journal of Endocrinology 146 3-8.

Cockle SM, Aitken A, Beg F \& Smyth DG 1989 A novel peptide, pyroglutamylglutamylproline amide, in the rabbit prostate complex, structurally related to thyrotrophin-releasing hormone. Journal of Biological Chemistry 264 7788-7791.

Cockle SM, Prater GV, Thetford CR, Hamilton C, Malone PR \& Mundy AR 1994 Peptides related to thyrotrophin-releasing hormone (TRH) in human prostate and semen. Biochimica et Biophysica Acta 1227 60-66. 
Gkonos PJ, Kwok CK, Block NL \& Roos BA 1994 Identification of the human seminal TRH-like peptide pGlu-Phe-ProNH ${ }_{2}$ in normal human prostate. Peptides 15 1281-1283.

de Greef WJ, de Jong FH, de Koning J, Steenbergen J \& van der Vaart PDM 1983 Studies on the mechanism of the selective suppression of plasma levels of follicle-stimulating hormone in the female rat after administration of steroid-free bovine follicular fluid. Journal of Endocrinology 97 327-338.

Green CM, Cockle SM, Watson PF \& Fraser LR 1994 Stimulating effect of pyroglutamylglutamylprolineamide, a prostatic TRHrelated tripeptide, on mouse sperm capacitation and fertilizing ability in vitro. Molecular Reproduction and Development 38 215-221.

Green CM, Cockle SM, Watson PF \& Fraser LR 1996a Fertilization promoting peptide, a tripeptide similar to thyrotrophin-releasing hormone, stimulates the capacitation and fertilizing ability of human spermatozoa in vitro. Human Reproduction 11 830-836.

Green CM, Cockle SM, Watson PF \& Fraser LR $1996 b$ A possible mechanism of action for fertilization promoting peptide, a TRH-related tripeptide that promotes capacitation and fertilizing ability in mammalian spermatozoa. Molecular Reproduction and Development 45 244-252.

Harvey S, Trudeau VL, Ashworth RJ \& Cockle SM 1993 $p$ Glutamylglutamylprolineamide modulation of growth hormone secretion in domestic fowl: antagonism of thyrotrophin-releasing hormone action? Journal of Endocrinology 138 137-147.

de Herder WW, Uitterlinden P, Pieterman H, Tanghe HLJ, Kwekkeboom DJ, Pols HAP, Singh R, van de Berge JH \& Lamberts SWJ 1994 Pituitary tumour localization in patients with Cushing's disease by magnetic resonance imaging. Is there a place for petrosal sinus sampling? Clinical Endocrinology 40 87-92.

Hökfelt T, Tsuruo Y, Ulfhake B, Cullheim S, Ardvisson U, Foster GA, Schulzberg M, Schalling M, Arborelius L, Freedman J, Post C \& Visser TJ 1989 Distribution of TRH-like immunoreactivity with special reference to co-existence with other neuroactive compounds. Annals of the New York Academy of Sciences 553 76-105

Iversen E 1986 Thyrotropin-releasing hormone cannot be detected in plasma from normal subjects. Journal of Clinical Endocrinology and Metabolism 63 516-519.

Iversen E 1995 Thyrotropin releasing hormone. Occurrence and role outside the central nervous system. Danish Medical Bulletin 42 257-268.

Khan Z, Aitken A, del Rio-Garcia J \& Smyth DG 1992 Isolation and identification of two neutral thyrotropin releasing hormone-like peptides, pyroglutamylphenylalanineproline amide and pyroglutamylglutamineproline amide, from human seminal fluid. Journal of Biological Chemistry 267 7464-7469.

Klootwijk W, Vaessen LMB, Bernard BF, Rondeel JMM, de Greef WJ \& Visser TJ 1995 Production and characterization of monoclonal and polyclonal antibodies against thyrotropin-releasing hormone. Hybridoma 14 285-290.

Klootwijk W, de Herder WW, Kwekkeboom DJ, Lamberts SWJ, Krenning EP, Visser TJ \& de Greef WJ 1996 High serum levels of the thyrotropin-releasing hormone-like peptide pyroglutamylglutamyl-prolineamide in patients with carcinoid tumours. Journal of Clinical Endocrinology and Metabolism 81 2816-2820.
Klootwijk W, de Boer RDH, Sleddens-Linkels E, Cockle SM, de Herder WW, Bauer K, Visser TJ \& de Greef WJ 1997a Urinary excretion of the TRH-like peptide pyroglutamyl-glutamylprolineamide in rats. Journal of Endocrinology 153 411-421.

Klootwijk W, Sleddens-Linkels E, de Boer RDH, Jansen CA, Autar R, de Herder WW, Boevé ER, Visser TJ \& de Greef WJ $1997 b$ Renal clearance of the thyrotropin-releasing hormone-like peptide pyroglutamyl-glutamyl-prolineamide in humans. Journal of Clinical Endocrinology and Metabolism 82.

Lambalk CB, de Koning J, van Kessel H, van Rees GP \& Schoemaker J 1985 Calculation of the intra-assay variation per assay and its relevance to LH pulse detection. IRCS Medical Science $\mathbf{1 3}$ $1183-1184$.

Linden H, del Rio Garcia J, Huber A, Kreil G \& Smyth D 1996 The TRH-like peptides in rabbit testis are different from the TRH-like peptide in the prostate. FEBS Letters 379 11-14.

Neri G, Malendovicz LK, Andreis P \& Nussdorfer GG 1993 Thyrotropin-releasing hormone inhibits glucocorticoid secretion of rat adrenal cortex: in vivo and in vitro studies. Endocrinology 133 511-514.

Pekary AE, Meyer NV, Vaillant C \& Hershman JM 1980 Thyrotropin-releasing hormone and a homologous peptide in the male reproductive system. Biochemical and Biophysical Research Communications 95 993-1000.

Pekary AE, Lukaski HC, Mena I, Smith SM, Bhasin S \& Hershman JM 1993 Testosterone increases TRH biosynthesis in epididymis but not heart of zinc-deficient rats. Peptides 14 315-324.

Rondeel JMM, Klootwijk W, Linkels E, de Greef WJ \& Visser TJ 1994 Neural differentiation of the human neuroblastoma cell line IMR 32 induces production of a thyrotropin-releasing hormone-like peptide. Brain Research 665 262-268.

Rondeel JMM, Klootwijk W, Linkels E, van Haasteren GAC, de Greef WJ \& Visser TJ 1995a Regulation of the TRH-like peptide pyroglutamyl-glutamyl-prolineamide in the rat anterior pituitary gland. Journal of Endocrinology 145 43-49.

Rondeel JMM, Klootwijk W, Linkels E, Jeucken PHM, Allaerts W, Hofland LJ, Everts ME, Kramer P, de Jong FH, van Haasteren GAC, Cockle SM, Visser TJ \& de Greef WJ 1995b Further studies on the regulation, localization and function of the TRH-like peptide pyroglutamyl-glutamyl-prolineamide in the rat anterior pituitary gland. Journal of Endocrinology 146 293-300.

Schauder B, Schomburg L, Köhrle J \& Bauer K 1994 Cloning of a cDNA encoding an ectoenzyme that degrades thyrotropin-releasing hormone. Proceedings of the National Academy of Sciences USA 91 9534-9538.

Scheele F, Lambalk CB, Schoemaker J, van Kessel H, de Koning J, van Dieten JAMJ, van Rees GP \& de Vries Robles-Korsen TJM 1987 Patterns of LH and FSH in men during high frequency blood sampling. Journal of Endocrinology 114 153-160.

Veldhuis JD, Johnson ML \& Seneta E 1991 Analysis of copulsatility of anterior pituitary hormones. Journal of Clinical Endocrinology and Metabolism 73 569-576.

Received 1 April 1997

Accepted 30 May 1997 